\title{
Dugald River case study - the importance of understanding your orebody and designing your mine for maximum value
}

\author{
P Harris MMG Limited, Australia
}

\begin{abstract}
The Dugald River Zn-Pb-Ag deposit was first discovered pre-1880, and is regarded as one of the largest and highest-grade undeveloped deposits of zinc in the world with a mineral resource of $55 \mathrm{Mt}$ at $13.4 \%$ zinc, $2.1 \%$ lead and $36 \mathrm{~g} / \mathrm{t}$ silver. It was largely neglected until the 1950s, when systematic exploration was conducted; however, due to low base metal prices and the discovery and development of nearby deposits, the orebody remained undeveloped.

Exploration decline development started in February 2012, providing early access to the orebody. Towards the end of 2012, exposure of the geological conditions in oredrive development and from underground diamond drilling highlighted a more complex and challenging mining environment than understood from the feasibility study.

The Dugald River project was approved in December 2012, with a technical risk mitigation programme established to better understand the orebody characteristics and assess critical parameters related to the potentially more complex ground conditions and resulting dilution, stope sizes and general mineability.

The technical risk mitigation programme concluded that ore variability was higher than expected and that ground conditions were likely to be worse than anticipated. Mine method and business options reviews were recommended to determine the path forward to fully maximise the value of the Dugald River deposit.

The economic evaluation following these reviews illustrated the high sensitivity of mining and geotechnical design assumptions to mine production rate, plant feed grade and, ultimately, project value. As a result, the project was suspended in September 2013 to enable further investigation to determine mining and geotechnical design parameters and practical mine operating performance.

A trial stoping programme and a geological and geotechnical work program were designed to significantly improve orebody knowledge and to derive mining and geotechnical design parameters that could be used to develop a revised mine design and mine production schedule with a much greater level of confidence.

The programmes were highly successful in reducing technical risk and project uncertainty. The final result is a revised mine design with a $1.5 \mathrm{Mtpa}$ production rate and an estimated 28 year mine life. Value engineering of the process plant and associated surface infrastructure to match the mine production rate have resulted in an updated development plan that fully maximises the long-term value of the Dugald River deposit.
\end{abstract}

It is the purpose of this paper to explain in some detail the evolution in the technical understanding of the Dugald River deposit following its acquisition by MMG Limited. The advancement of technical knowledge not only led to a reduction in project risk and uncertainty, but also had significant impact on mine design and the project development plan.

The importance of understanding and continually responding to the unique characteristics of an ore body and designing your project to maximise long-term value has been reinforced at Dugald River.

\section{Introduction}

The Dugald River Zn-Pb-Ag deposit is located 85 km northwest of Cloncurry, Queensland (Figure 1). It is one of the largest undeveloped zinc deposits in the world and is of a significantly higher grade than other large 
undeveloped deposits (Figure 2). It was discovered in the 1870s, but it was not until the 1950s that Zinc Corporation, an antecedent company of Conzinc Riotinto of Australia Limited (CRA), undertook systematic exploration of the prospect. Metal prices at the time did not support development.

\section{Queensland}

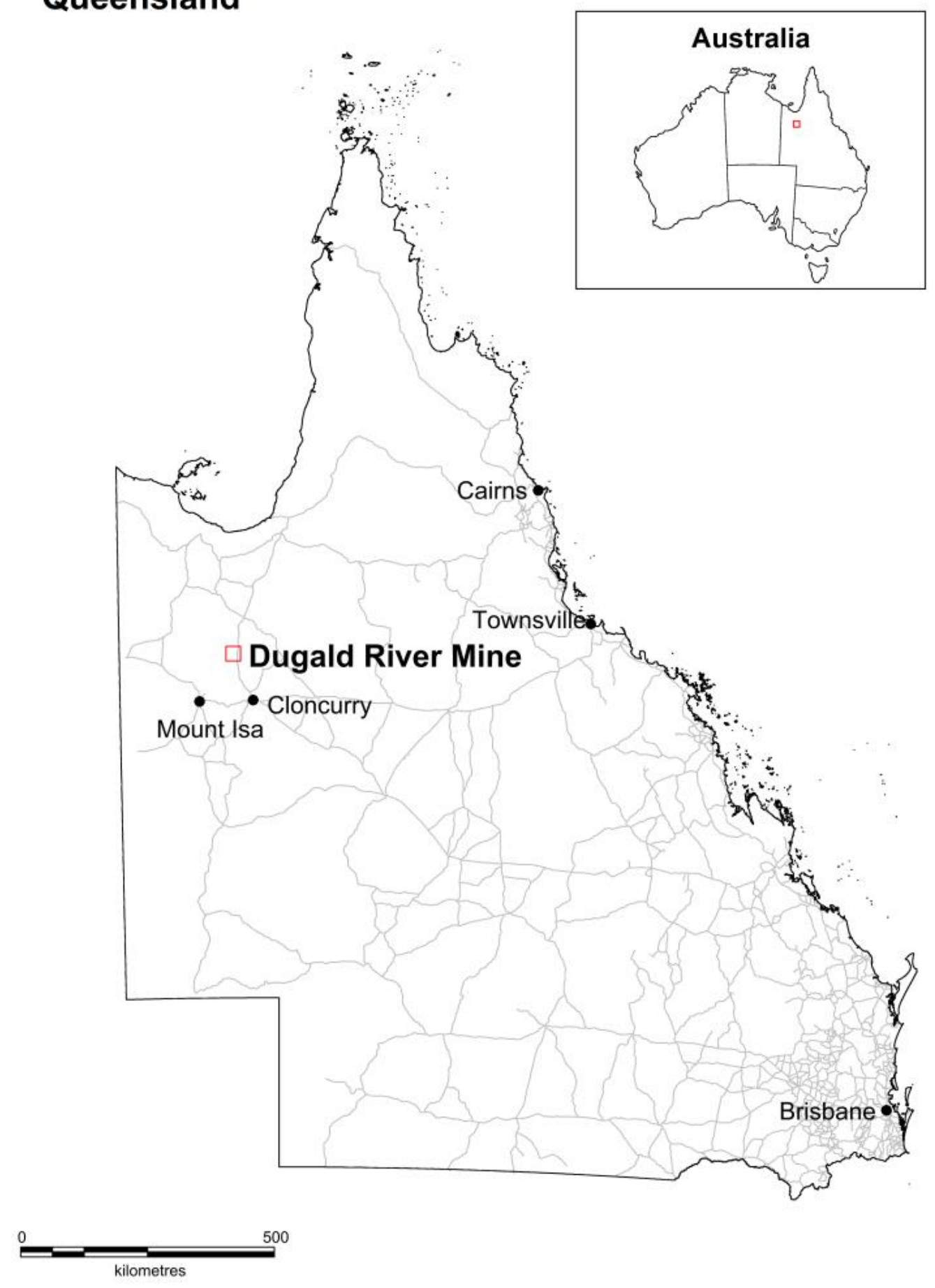

Figure 1 Location of the Dugald River project 


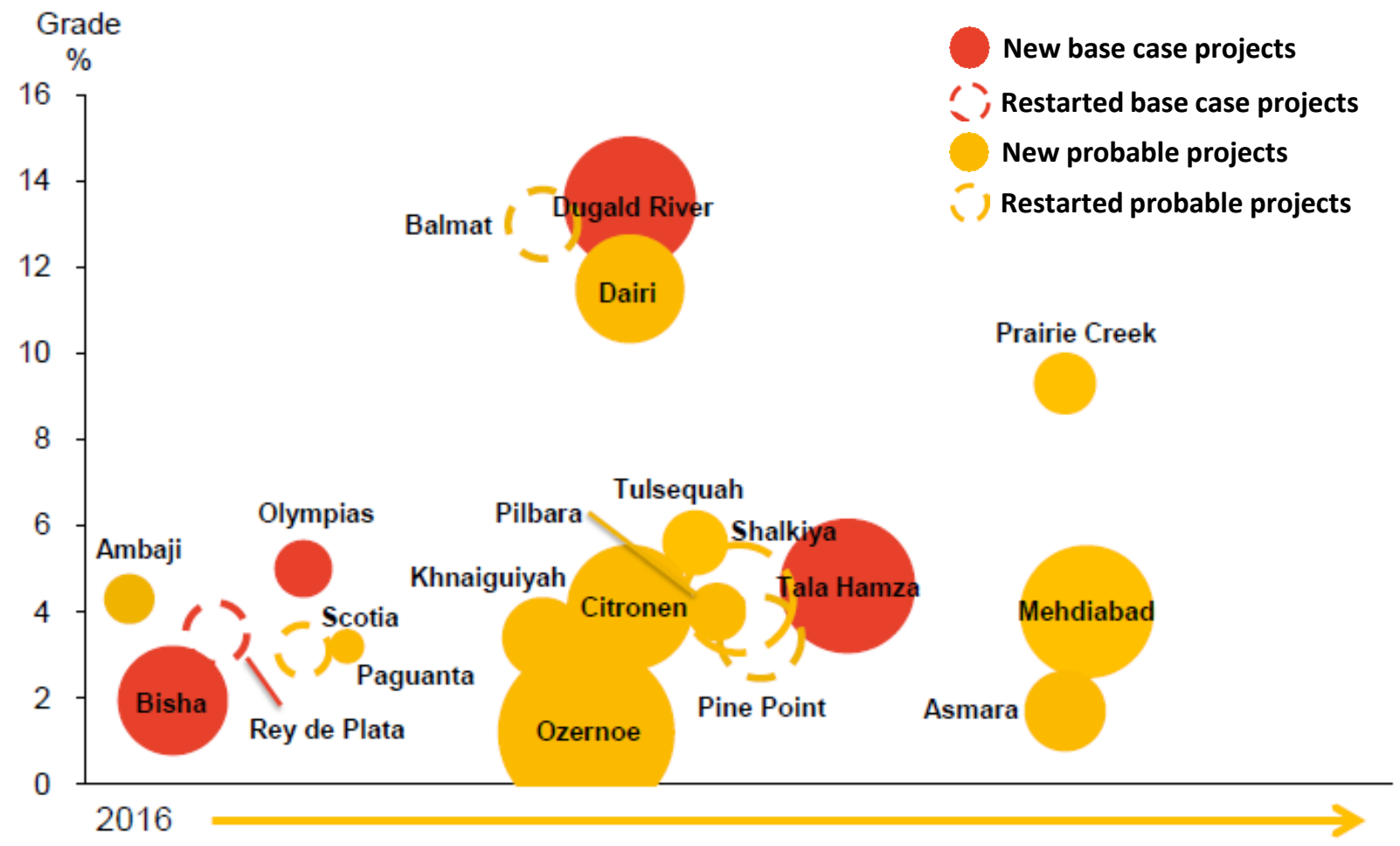

Figure 2 Comparison of undeveloped zinc deposits (Wood McKenzie, company reports)

Exploration of the Dugald River prospect by CRA and Pasminco Limited continued during the 1990s, but, again, poor base metal prices together with predicted high levels of manganese reporting to the zinc concentrate and the discovery and development of the Century and Cannington deposits meant that the orebody remained undeveloped. Zinifex Limited acquired the project from Pasminco in 2004 and in December 2006 completed the preliminary feasibility study. In July 2008, Zinifex Limited merged with Oxiana Limited to form OZ Minerals. In June 2009, MMG Limited acquired the Dugald River project as part of the acquisition of the majority of $\mathrm{OZ}$ Minerals assets.

\subsection{Dugald River project timeline}

The key phases of the project post MMG Limited acquisition were the 2009 feasibility study (MMG Limited 2009), project execution, the mining method review (MMR) (AMC Consultants 2013), trial stoping programme and the updated pre-feasibility/development plan (Figure 3). The technical design methods used at each stage and subsequent mining parameters and rates show the progression of increasing knowledge along with decreasing risk.

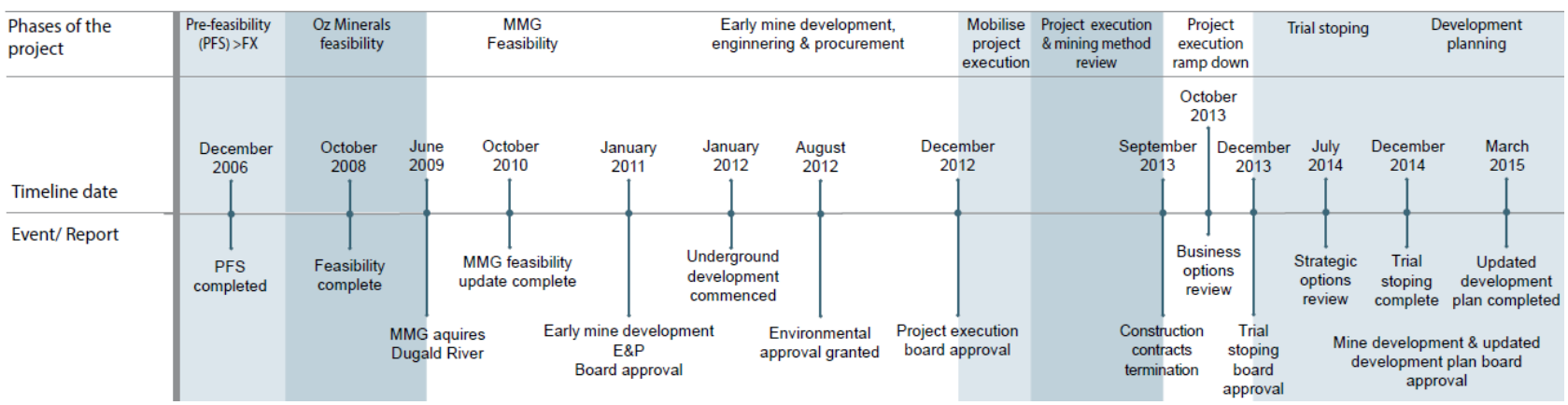

Figure 3 Dugald River project historical milestones 


\section{9 feasibility study}

The 2009 Dugald River feasibility study was based on the information and understanding available at the time. It confirmed the technical and financial viability of the project with an identified total resource of $54 \mathrm{Mt}$ at $12.7 \% \mathrm{Zn}, 2.0 \% \mathrm{~Pb}$ and $39 \mathrm{~g} / \mathrm{t} \mathrm{Ag}$ from which ore could be mined from underground methods, producing saleable concentrate containing 4,567,000 tonnes of zinc concentrate, 579,000 tonnes of lead concentrate and $19 \mathrm{Moz}$ of silver over an operating life of 23 years (MMG Limited 2009).

\subsection{Geological interpretation}

Geological analyses and interpretation were completed from a total of 291 drill hole intercepts, as shown in Figure 4. A variety of drilling techniques had been employed between 1939 and 2008; these include NQ, $\mathrm{NQ2}, \mathrm{HQ}, \mathrm{BQ}$ and $\mathrm{PQ}$ diamond and reverse circulation drilling. Standard geological logging of lithology, alteration, mineralisation, magnetic susceptibility and structure were completed. Basic geotechnical data was acquired from drill core including rock quality designation (RQD) and fracture frequency. Detailed geotechnical logging was carried out on 11 holes, which included discontinuity count, type, infill and texture/condition. A diamond drilling density of $25 \times 25 \mathrm{~m}$ was recommended to adequately drill out the orebody.

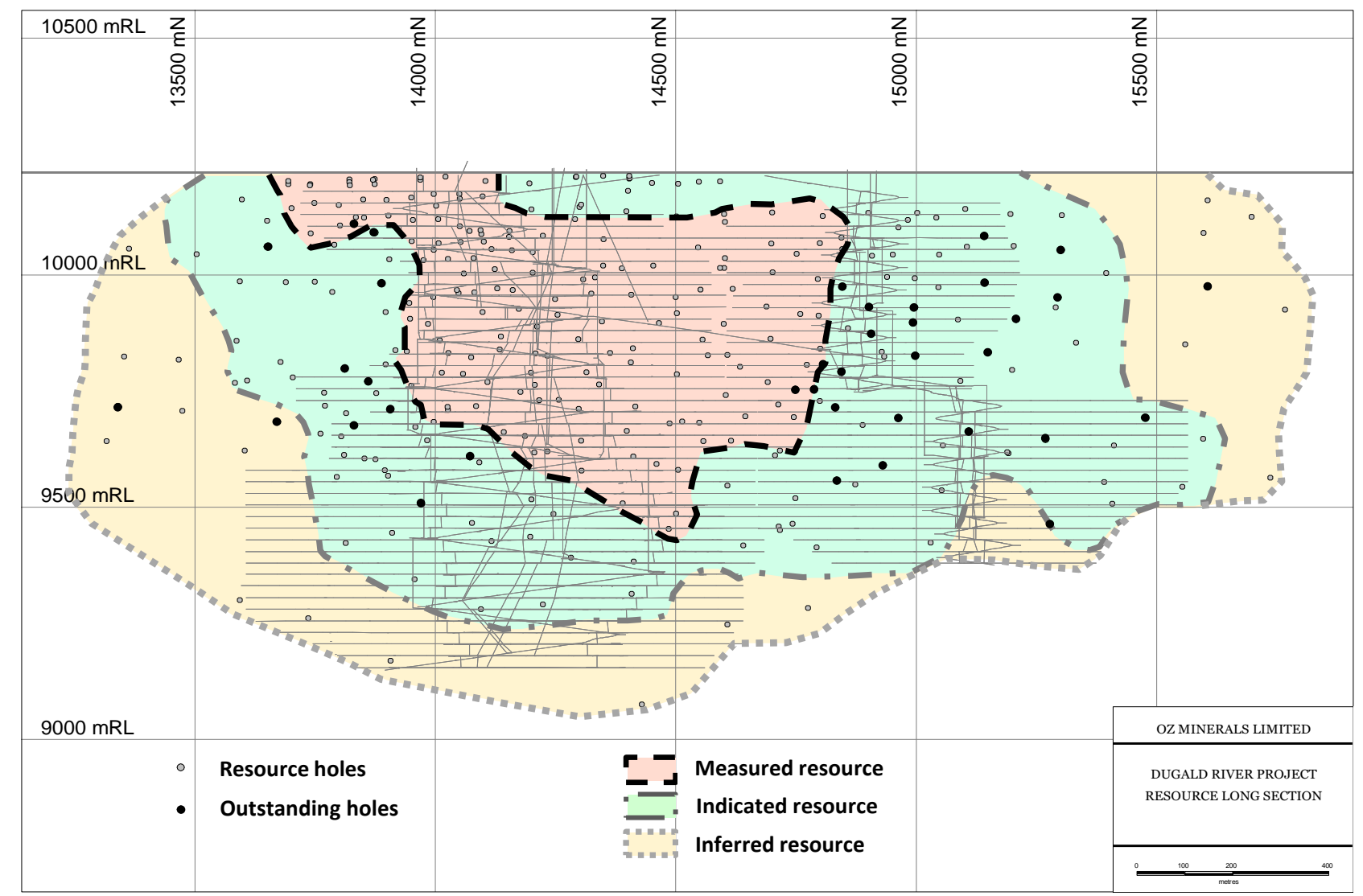

Figure 4 Resource long section from the 2009 feasibility study (MMG Limited 2009)

The Dugald River deposit occurs within the eastern fold belt of the Mount Isa Inlier, and the Dugald lode is hosted within a steeply dipping black slate sequence of low metamorphic grade. The deposit is a steep dipping tabular orebody, extending approximately $2 \mathrm{~km}$ along strike and to a depth of approximately $1 \mathrm{~km}$. The orebody strikes approximately north-south (mine grid north), dips between 45 to $85^{\circ}$ to the west, and varies in true thickness from 1 to $35 \mathrm{~m}$. The area of greatest ore thickness occurs in the central part of the orebody between the depths of 200 and $600 \mathrm{~m}$, which coincides with the area of flattest dip (Figure 5). 
The hanging wall slates (HWSL) occur in the immediate hanging wall of the Dugald Lode and typically vary in thickness between 50 and $100 \mathrm{~m}$. In the area where the Dugald lode dip flattens to less than $50^{\circ}$, the thickness can be as little as $10 \mathrm{~m}$. Muscovite schist, mafic porphyry and calc-silicate units are to the west of the hanging wall of the HWSL. The HWSLs typically consist of massive, fine-grained dark grey slate, spotted in places, to laminated, fine-grained dark grey to light grey slates, often with carbonate veining.

The footwall slates (FWSL) and limestones are to the footwall of the Dugald lode. A narrow zone of FWSL grades to limestone over a distance of up to $50 \mathrm{~m}$. In some areas, the footwall slates are absent and the limestone forms the footwall contact with the Dugald lode. The footwall slates are almost identical in geological and geotechnical parameters to the HWSL.

The orebody is hosted by slate and is dominated by sphalerite and pyrrhotite/pyrite with minor galena, arsenopyrite and chalcopyrite. It ranges from massive sulphide breccias with large angular clasts of slate to stringer veins hosted in slate.

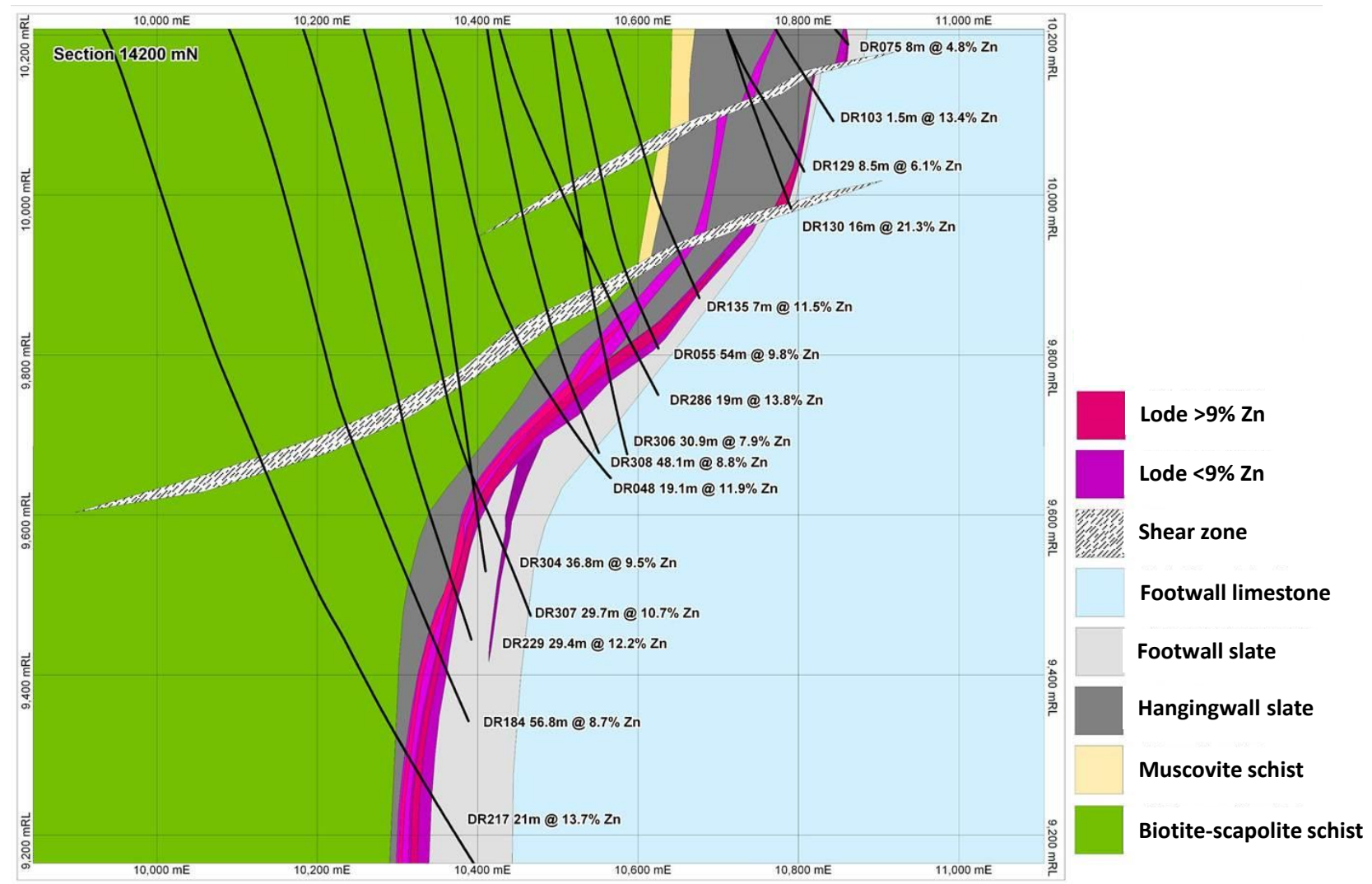

Figure 5 Cross-section through the Dugald River orebody based on the 2009 feasibility study information $(14,200 \mathrm{mN})$

\section{$2.2 \quad$ Geotechnical model}

The geotechnical section of the 2009 feasibility study (MMG Limited 2009) identified four geotechnical domains for which the rock mass conditions are broadly similar in terms of expected response to underground mining:

- Hanging wall black slates.

- Hanging wall shear zone (HWSZ).

- Dugald lode.

- Footwall slates and limestone. 
The feasibility study identified that the key aspect that dictated the likelihood and nature of instability of the stope hanging wall was the presence of the HWSZ. The HWSZ is a zone consisting of varying degrees of fragmented, sheared and crushed graphitic black slates (Figure 6). It is commonly a single zone varying in width from 0.5 to $5.0 \mathrm{~m}$. In some areas, however, it occurs as two or more zones of poor rock quality rock separated by narrow zones (of the order of 1 to $2 \mathrm{~m}$ ) of intact rock consisting of hanging wall black slates or Dugald lode lithologies. These zones can extend to widths of approximately $10 \mathrm{~m}$. The HWSZ was interpreted as either:

- A continuous zone within the hanging wall sequence, which undulates relative to the Dugald lode hanging wall contact.

- A series of shear structures that splay from the Dugald lode hanging wall contact at a low angle and terminate some distance (greater than $50 \mathrm{~m}$ normal to the contact) into the hanging wall.

- An anastomosing shear system with shear splays stepping from bedding to foliation, resulting in rotation of blocks and containing both brittle and ductile deformation.

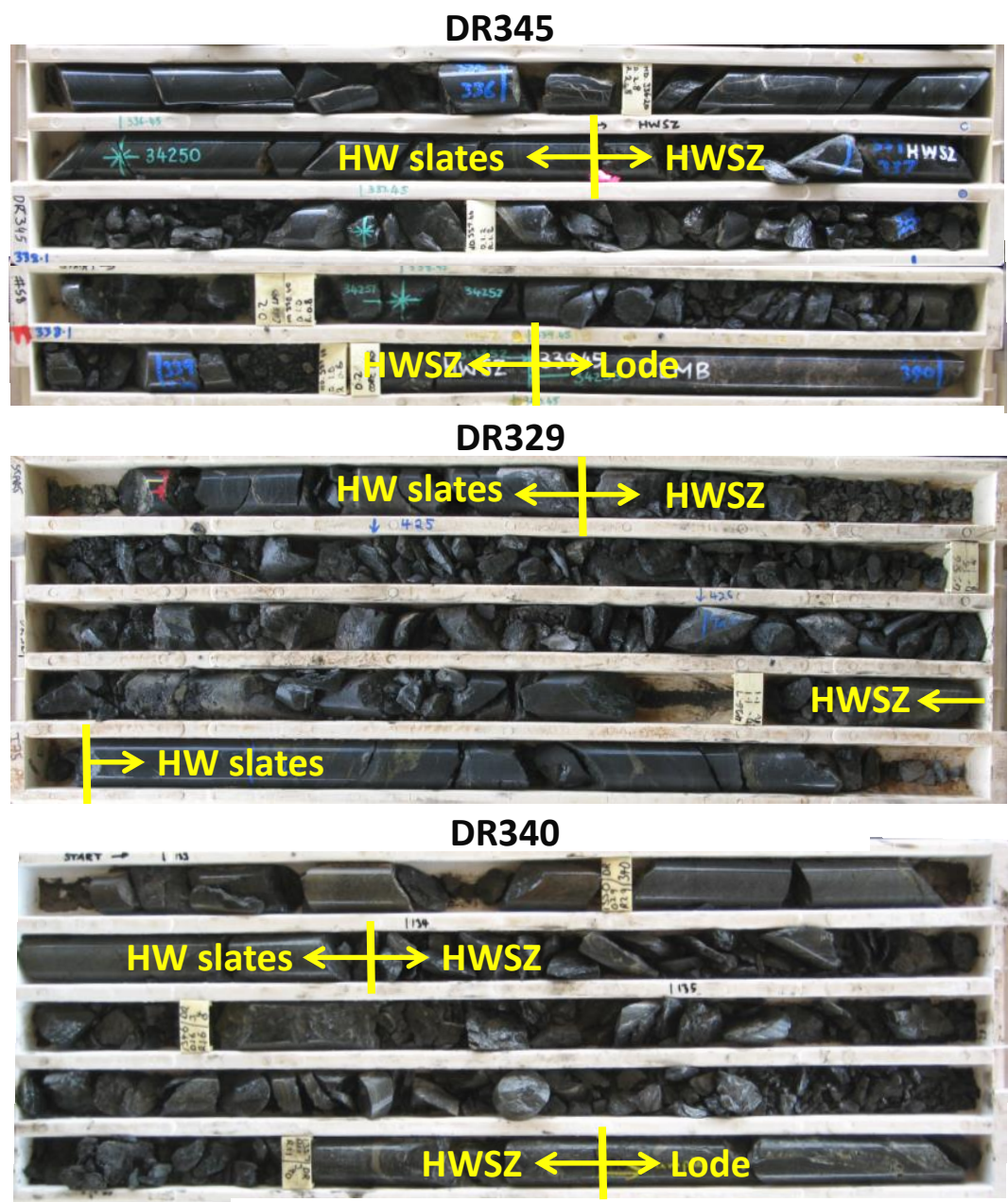

Figure 6 Examples of diamond drill core of the hanging wall shear zone

A long section (Figure 7) of the Dugald lode hanging wall categorises the hanging wall depending upon the relative distance of the HWSZ from the orebody hanging wall. Red areas on the plot indicate Category 1 zones in which the HWSZ is interpreted to occur within $5 \mathrm{~m}$ of the hanging wall of the high grade ore contact. Green areas indicate Category 2 zones in which the HWSZ is interpreted to occur between 5 and $10 \mathrm{~m}$ from the hanging wall contact. Blue areas indicate Category 3 zones in which the HWSZ is interpreted to occur at a distance greater than $10 \mathrm{~m}$ from the hanging wall contact. 


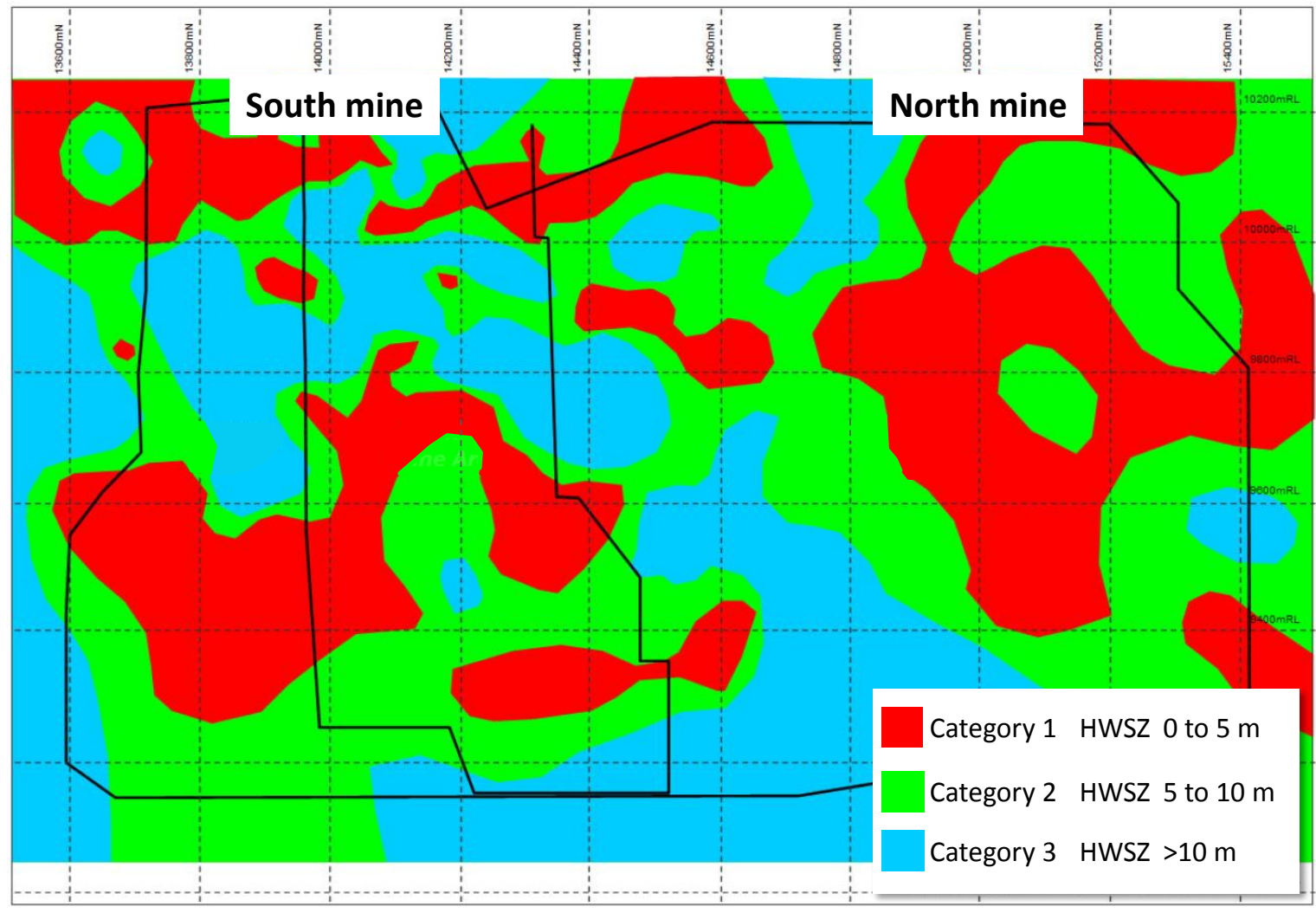

Figure 7 South-north long section (west facing) derived from the 2009 feasibility study showing hanging wall category based on proximity of HWSZ to hanging wall contact

\subsection{Mining method and stope design}

A range of mining options were assessed to establish the optimal mining method and project scale. Financial evaluation showed that open pit options had negative financial returns and poor resource recoveries. Underground mining options of 2.0 and 2.4 Mtpa had similar positive financials with a $2.0 \mathrm{Mtpa}$ option selected, as it had a more achievable vertical advance rate of about $70 \mathrm{~m} / \mathrm{y}$.

For ore haulage and ventilation purposes, the orebody was divided into north and south mines with separate declines for each. The north mine accessed the narrower and steeper side of the orebody, producing at $0.6 \mathrm{Mtpa}$, and supplemented the main production contained in the south mine, producing at 1.4 Mtpa. The proposed mining method was sublevel open stoping (SLOS) with cemented paste backfill, using longitudinal bench stopes in narrow ore zones. For scheduling purposes, each side of the orebody was divided into mining panels containing between four and six sublevels. Stope sequence within panels was planned from the bottom level and moved upward and laterally to form close-out pillars.

The empirical Mathews stability graph method was used to determine stable stope dimensions, based on hanging wall rock mass properties. The proposed level spacing was $25 \mathrm{~m}$ (vertical distance from floor to floor), with a nominal stope length of $25 \mathrm{~m}$, but variations where required to suit the local rock mass were expected.

It was identified that in areas of competent rock, the stope strike length may be longer (up to $30 \mathrm{~m}$ ), whilst areas influenced by the HWSZ may require shorter lengths of 15 to $20 \mathrm{~m}$. The distance and orientation of the stope hanging wall to the HWSZ would be the key aspect that dictated the likelihood and nature of stope instability. Stope dilution was based on a constant $1.5 \mathrm{~m}$ of overbreak into hanging walls and $0.5 \mathrm{~m}$ of overbreak into footwalls. These design parameters did not account for specific local rock mass properties or the positions of individual stopes in the overall extraction sequence. 


\subsection{Known risks with the project}

The feasibility study (MMG Limited 2009) identified a number of key technical risks associated with the project. These were that:

- Orebody thickness, continuity, grade and ore quality may be materially different to what was anticipated from available drill hole data.

- Mining ground conditions may be more challenging than prior assumptions, resulting in increased dilution.

- Stope activity cycle may be slower than expected, reducing productivity and/or increasing mine unit costs.

\section{$3 \quad$ Project approval and technical risk mitigation}

In December 2012, the MMG Limited board approved the development and construction of the Dugald River mine. A technical risk mitigation programme was established to better understand the orebody characteristics and assess critical parameters related to the potentially more complex ground conditions and resulting dilution, stope sizes and general mineability.

As mine development continued and the upper levels of the orebody became accessible, further information regarding the geological and geotechnical characteristics became available. This information from oredrive development and from underground diamond drilling identified more complex and challenging conditions than prior assumptions.

The technical risk mitigation program identified that ore variability was higher than expected, with the orebody pinching in/out, anastomosing within intervals less than $30 \mathrm{~m}$, branching out into two then reconnecting, and being cut-through by shears that were highly graphitic in nature. This new information concluded that neither the orebody nor the hanging wall shear were single, continuous sheets, as modelled in the feasibility study.

Given the potential impact of this emerging scenario of potentially higher dilution and high ore variability - resulting in lower feed grade to the concentrator, potentially lower mine production and/or a slower ramp up due to smaller stope sizes, and higher operating costs - the decision was made to review the proposed mine method.

As a result, MMG commissioned a review of the proposed mining method and development options to maximise the value of Dugald River for MMG Limited.

\subsection{Mining method review}

A MMR (AMC Consultants 2013) was initiated to carry out a technical review of alternate mining methods, given the evolving understanding of geotechnical characteristics and mining rates and costs. Mining methods evaluated included open pit, sublevel caving, uphole retreat, underhand cut-and-fill and bench stoping (continuous and modified). Open pit and cut-and-fill were not feasible options. Uphole retreat was also not feasible on geotechnical grounds; however, the method could be suitable in isolated areas of the mine. Sublevel caving was considered a possible method, but final expected grades from this method would not result in an economic outcome due to the very high capital overhead. Bench mining, both continuous and modified, was identified as a viable alternative to SLOS in areas where the orebody was narrow ( $<8 \mathrm{~m}$ horizontal).

As part of the review, a detailed engineering assessment of ground conditions was completed. In addition to the 2009 feasibility study information, further diamond drill hole information and over $6,000 \mathrm{~m}$ of underground development, including oredrives, were available. The increasing structural complexity of the lode was acknowledged with the identification of multiple large-scale shallow dipping faults and lode-parallel shears. The review generally confirmed the 2009 feasibility study's geotechnical model and 
the existence of the HWSZ. The emphasis was to define the position and thickness of the HWSZ, the presence or absence of the hanging wall beam (rock between HWSZ and stope hanging wall) and to characterise this beam. This was aided by the development of a geotechnical block model. Where the beam was non-existent or considered likely to fail, ore skins were left against the hanging wall.

The modified stability graph method was again used to determine stable stope dimensions, but these included empirical relationships for dilution with a methodology that had been developed by Capes (2009) for the George Fisher underground mine. A benefit of the George Fisher work is that it specifically applies to variably bedded and blocky graphitic rock masses, similar to the rock mass at Dugald River.

The MMR (AMC Consultants 2013) concluded that there was a significant risk of stope collapse with the stope sizes ( $25 \mathrm{~m}$ height $\times 25 \mathrm{~m}$ strike) outlined in the 2009 feasibility study. As a consequence, while the original mining method of SLOS was confirmed as the most appropriate for the bulk of the orebody, a smaller stope size of $25 \mathrm{~m}$ height $\times 15 \mathrm{~m}$ strike was recommended. Furthermore, the bench mining method was proposed as a marginally better approach in the narrower part of the orebody. The MMR predicted an average stope hanging wall overbreak of $1.1 \mathrm{~m}$. However, it was suggested that considerable ore pillars be left adjacent to the hanging wall where the HWSZ was within $1.5 \mathrm{~m}$ of the orebody. Most other mining parameters were not changed from the 2009 feasibility study. Production rates of the newly proposed mining approach reduced from $2 \mathrm{Mtpa}$ to $1.55-1.75 \mathrm{Mtpa}$, a reduction up to greater than $20 \%$.

Due to the stricter geotechnical controls, the modifications to the mine design had an adverse impact on project economics, stemming from the consequential reduction in inventory, lower annual mine production and resultant higher mining costs.

\subsection{Business options review}

The business options review (BOR) (MMG Limited 2013) was initiated to quantify the financial impacts of the changes resulting from the MMR, and recommend the path to take the Dugald River project forward in a way that maximised long-term value for MMG Limited.

Financial analysis was undertaken to understand the economics of various project options, including the development of a standalone facility and the use of existing infrastructure at MMG's Century mine.

The use of existing Century infrastructure significantly reduced the project capital but resulted in lower free cash flow during the operating phase of the project due to high cost of ore transportation by road between the two sites.

The key conclusion from the financial analysis was that further work was required to determine geotechnical assumptions and practical mine performance before surface infrastructure requirements could be established. It was recognised that while the latest geotechnical interpretation was based on the latest available information, it would be beneficial to gain practical operating experience. Additional enhancement of the project value would also be required before further expenditure. The overall conclusion of the BOR was that development of the mine at Dugald River should continue with a targeted trial stoping program. It also established that construction of the processing plant should continue to be deferred until completion of the trial stoping program and mining parameters were more definitively established.

\subsection{Project suspension}

Due to the identification of geotechnical conditions more challenging than prior assumptions, the construction of certain surface infrastructure facilities was suspended in September 2013. A trial stoping program was approved in December 2013 and commenced in March 2014. 


\section{$4 \quad$ Trial stoping}

The trial stoping programme was designed to address the three main uncertainties that triggered the suspension of the project:

- To gain a better understanding of the structural geology and ground conditions in the hanging wall.

- To verify that the SLOS mining method and relevant stope dimensions can keep the overbreak (and dilution) under control.

- Test the method to forecast overbreak (and dilution).

In addition, the trial stoping programme collected a wide range of mining productivity and cost information for input into mine production schedules and economic evaluations. Updating previous assumptions and benchmarking information with actual productivities and real cost information had a significant impact on reducing uncertainty and development of an updated development plan.

The trial stoping program was concluded in December 2014, under budget and within the timeframe allocated. It successfully extracted $335 \mathrm{kt}$ of ore from 19 stopes with strike lengths and stope heights exceeding the MMR stope design assumptions. Strike lengths ranged from 15 to $30 \mathrm{~m}$ with stope dilution $10 \%$ less than the original project assumptions and $2.7 \%$ more than the MMR assumptions (but with larger stope strike lengths). Recovery rates from broken material in the stopes were higher than both the feasibility study and MMR assumptions.

The trial showed that with the right ground conditions, sublevel open stopes with a $25 \mathrm{~m}$ level spacing and strike lengths up to $30 \mathrm{~m}$, with appropriate ground support, controlled drill and blasting and cemented backfill, could be safely extracted with acceptable overbreak, underbreak and dilution.

More detailed descriptions of the trial stoping program and outcomes can be found in de Vries et al. (2015), Hassell et al. (2015a; 2015b) and Carswell et al. (2015). Key mine design and scheduling parameters were established, including:

- Required drilling density for orebody complexity for the completion of diamond drilling and orebody interpretation before oredrive development.

- Stope design parameters, including stope strike lengths, level spacing, longitudinal/transverse horizontal width change over distances, and cable bolt location and density.

- Stope drill and blast parameters such as drill hole orientation, explosive types and stope boundary stand-off distances to reduce overbreak.

- Oredrive and crosscut drive locations to achieve required stope drilling parameters.

- Dilution estimation for individual stopes, as opposed to a blanket approach across the orebody.

- The location and sizing of capital development in relation to orebody and major lithological units.

- Ground support standards based on expected damage from stress.

- Cemented rockfill (CRF) optimisation (average stope cement usage reduced from 5 to $<2.5 \%$ ) and placement methodologies.

- Standards for development through CRF.

- Updated in situ rock stress regime.

- Determination of mining production rates for longhole drilling, longhole charge-up, stope bogging (manual and remote) and CRF backfill placement from statistical analysis of measured rates. 
- Changes to stope designs including the development of a slot crosscut for stopes more than $8 \mathrm{~m}$ in width to allow parallel drilling of all holes in the slot. Crosscuts are not broken through to the footwall drive until a horizontal orebody thickness of $14 \mathrm{~m}$ is reached.

- Open hole hazards and re-work due to full slot firing are eliminated through combining slot and ring firings.

- Continuous steep chevron stope extraction sequence in each panel to minimise stress concentrations with no crown pillar formation. The crown stopes are mined as part of the sequence.

- Targeted location and sizing of regional pillars.

\section{$5 \quad$ Revised design parameters and assumptions}

In early 2015, the data obtained from the trial stoping was incorporated into the Dugald River updated development plan (MMG Limited 2015).

\subsection{Updated geological interpretation}

The lithological and mineralogical descriptions of the Dugald River deposit remain similar to the 2009 feasibility study (see Section 3.1). Advancements in knowledge were primarily associated with the structural model. The mechanisms of ore thickening and thinning, the paragenetic sequence of brittle faulting and the importance (and prevalence) of fault splays are now better understood. This was achieved through mapping of underground development headings, mapping of stope exposures and the re-interpretation of all datasets including the re-logging of 65,000 $\mathrm{m}$ of core.

The HWSZ is no longer regarded as a distinct feature with the recognition of four distinct fault sets, the interaction of which led to the variable hanging wall ground conditions. An example of the differences in interpretation is shown in the geological cross-sections of Figure 8. The complexity of the October 2014 interpretation compared to 2009 feasibility study is considerable with implications to mine design and layout. This level of geological detail could not have been determined with the diamond drill density available for the 2009 feasibility study or the recommended feasibility density of $25 \times 25 \mathrm{~m}$. It also required exposure of the underground workings to help interpret what was occurring.

The updated drill pattern requires an initial assessment at $40 \mathrm{~m}$ along strike $\times 30 \mathrm{~m}$ down dip density to be drilled out, assayed and analysed. Where an area is deemed that structural controls are simple, an infill drill pattern of $20 \mathrm{~m}$ along strike and $15 \mathrm{~m}$ down dip is required. Where the structural controls are deemed complex, a $15 \mathrm{~m}$ along strike and $10 \mathrm{~m}$ down dip infill drill pattern will be assigned. 


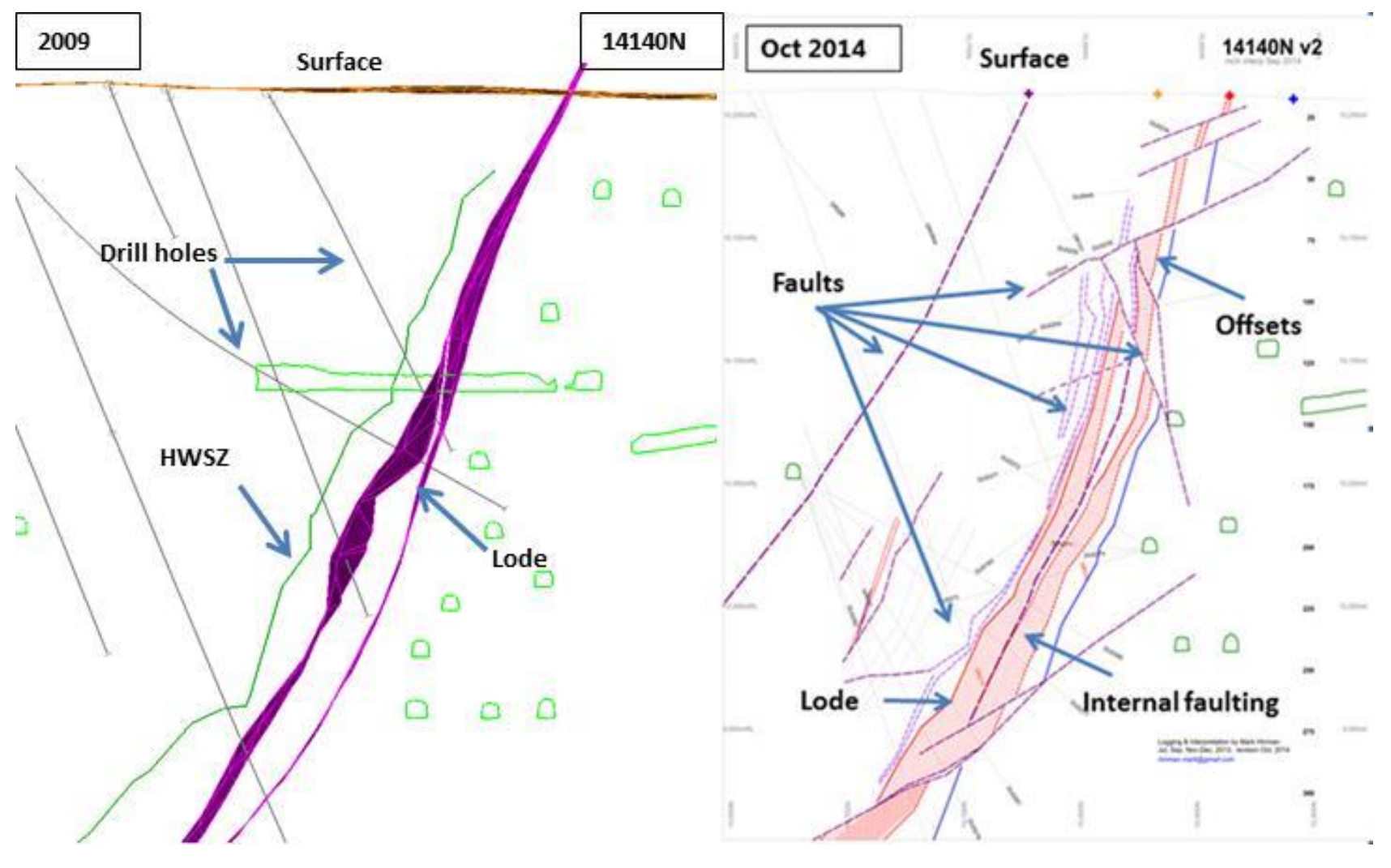

(a)

(b)

Figure 8 Section view of structural geology interpretation at 14,140 mN in 2009 (a) and updated in October 2014 (b) showing much more complexity in structural geology

\subsection{Updated geotechnical model}

The improvement in the structural model necessitated an improved geotechnical model with which to determine stope dimensions and dilution. A site-specific mechanistic overbreak model that defines the rock mass characteristics for bands adjacent to the stope hanging wall with data derived from the geotechnical database was developed. The model is superior to previous methods, as it is more sensitive to the presence of weak layers in the hanging wall that were the driving factor for stope instability. Hanging wall failure type is categorised into 12 principal categories and with 37 sub-categories, depending on the quality of each of the bands. Where overbreak is considered excessive or failure mechanism is unpredictable, the stope strike length is reduced. The model uses a geotechnical core logging data set that now consists of 775 geotechnically logged holes. This approach has proven to be more accurate than the modified $\mathrm{N}^{\prime}$ method used for the MMR.

The output of the model is 12 categories of mechanistic behaviours that are determined for the hanging wall, with specific stope strike length and dilution estimates for each category. Variable stope strike lengths have been determined, up to a maximum of $30 \mathrm{~m}$ (Figure 9). Average stope strike length across the orebody is $20 \mathrm{~m}$, which has increased from the recommendations of the MMR. Importantly, the technical risk has been reduced with a higher level of confidence in the results. This information has been used to optimise the updated Dugald River mine design and schedule. 


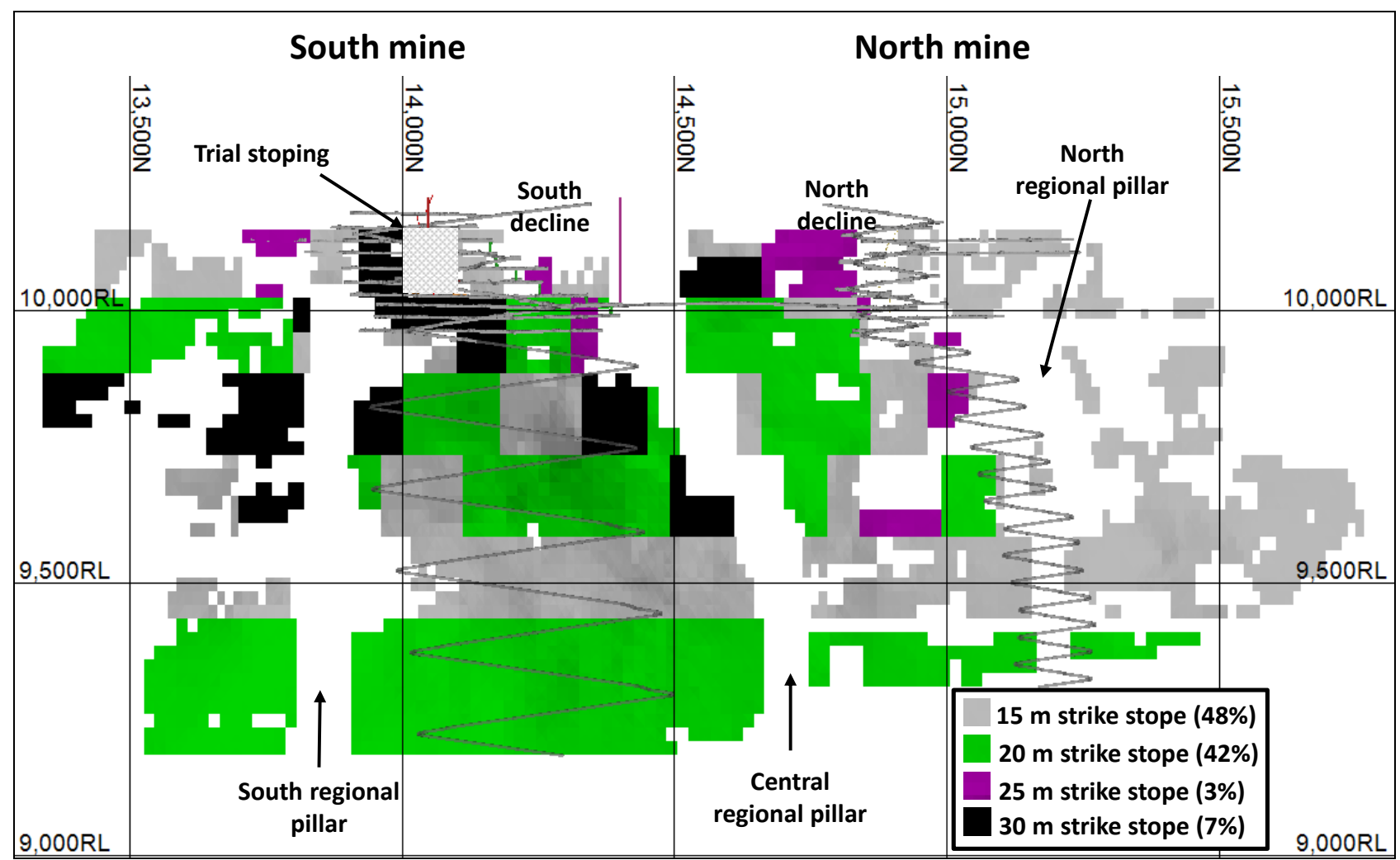

Figure 9 Long section looking west showing overall mine geometry and stope strike lengths

\subsection{Updated mining method and stope design}

The MMR recommended SLOS in the south mine and bench (continuous and modified) in the north mine, where the ore thickness was less than $8 \mathrm{~m}$, as the most technically feasible and financially viable option. The results from the trial stoping support the SLOS mining methodology in the south mine. A sublevel interval of $25 \mathrm{~m}$ will be applied across both mines with varying stope strike lengths $(15-30 \mathrm{~m})$ relative to localised ground conditions. The stoping sequence is planned to be mined as multiple panels in a bottom-up, continuous sequence, with the crown pillar extracted as part of the continuous sequence. The chevron sequence allows stoping to retreat toward the regional pillars, reducing the potential for smaller close-out pillars and unfavourable rock mass conditions forming (Figure 10). Backfill for the SLOS stopes will consist of cemented backfill. Bench stopes will use rockfill. 


\section{2 km along strike}

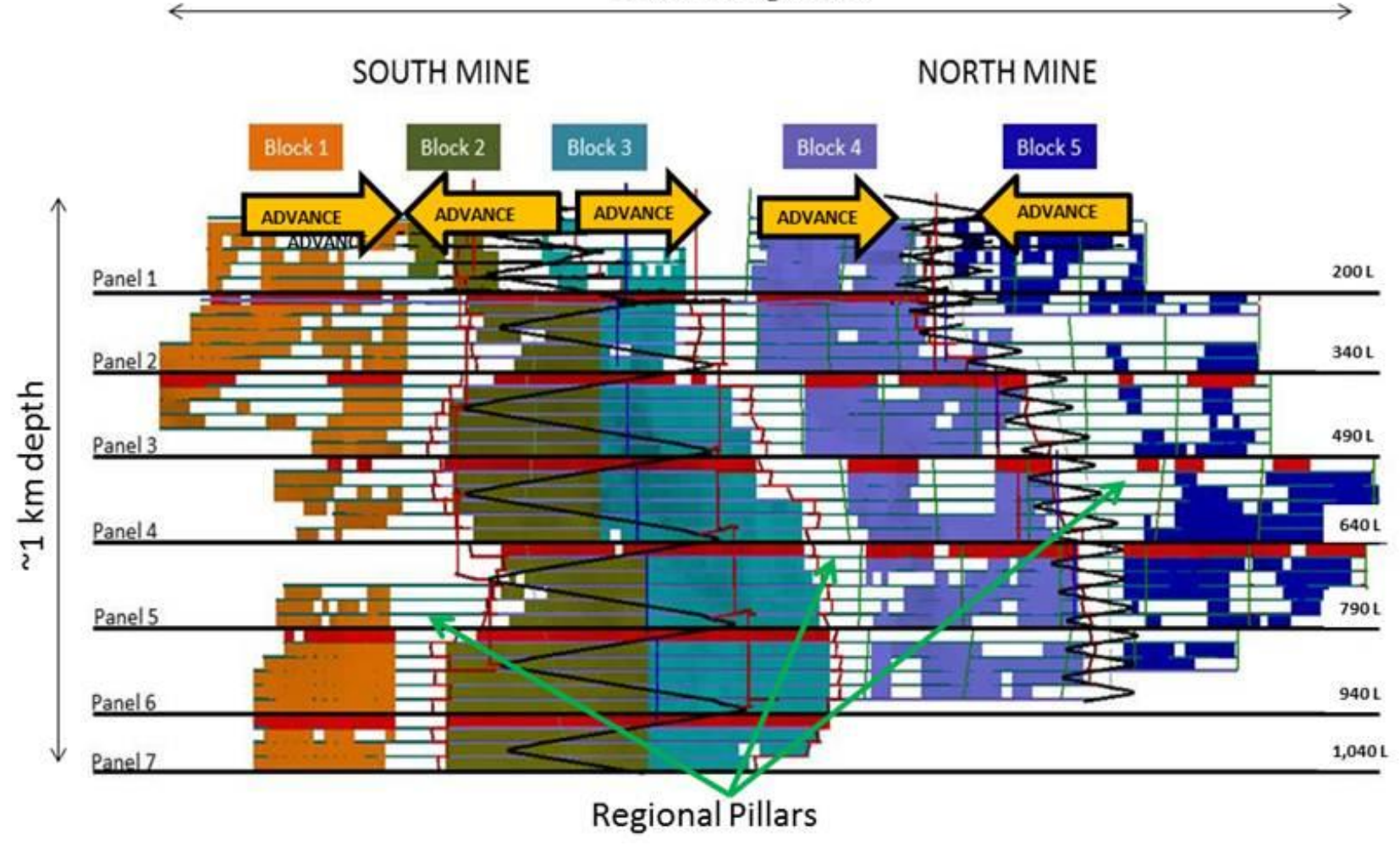

Figure 10 Long section of the Dugald River mining layout of panels and mining blocks

As part of the updated development plan, the mine design, extraction sequence and scheduling parameters were studied, and it was concluded that the optimal mine production rate is in the range of 1.5-1.8 Mtpa. When sequencing constraints and realistic development rates are taken into account, the maximum sustainable production rate of $1.5 \mathrm{Mtpa}$ has been assessed as the maximum practical mine production rate for the project.

\subsection{Comparison of key changes}

A comparison of the physical and technical parameters from initial project execution to 2015 are summarised in Table 1. The key changes include:

- Stope size reduction from $25 \times 25 \mathrm{~m}$ to a range of distribution of stope sizes based on geotechnical conditions, with sublevel spacing remaining as $25 \mathrm{~m}$.

- Mining inventory reduction from 43 to $38.2 \mathrm{Mt}$.

- Mine production rate reduction from 2.0 to $1.5 \mathrm{Mtpa}$.

- Forecast zinc metal produced reduced from 4.53 to $4.05 \mathrm{Mt}$ for life-of-mine (LOM). 
Table 1 Physical and technical parameters comparison

\begin{tabular}{|c|c|c|c|c|c|c|c|c|c|c|}
\hline \multirow{3}{*}{$\begin{array}{l}\text { Development } \\
\text { plan version }\end{array}$} & \multirow{3}{*}{ Date } & \multirow{3}{*}{$\begin{array}{c}\text { Development } \\
\text { description }\end{array}$} & \multicolumn{8}{|c|}{ Physical/technical parameters as inputs to economic evaluation } \\
\hline & & & \multirow{2}{*}{$\begin{array}{c}\begin{array}{c}\text { Mining } \\
\text { inventory }\end{array} \\
\text { Mt }\end{array}$} & \multirow{2}{*}{\begin{tabular}{|c|} 
Grade \\
zinc \\
$\%$ \\
average
\end{tabular}} & \multirow{2}{*}{$\begin{array}{c}\text { Mined } \\
\text { zinc } \\
\text { Mt }\end{array}$} & \multirow{2}{*}{$\begin{array}{c}\text { Mine } \\
\text { production } \\
\begin{array}{c}\text { Mtpa LOM } \\
\text { average }\end{array}\end{array}$} & LOM & $\begin{array}{l}\text { Plan } \\
\text { throughpu }\end{array}$ & $\begin{array}{l}\text { Zinc } \\
\text { ecoven }\end{array}$ & $\begin{array}{c}\text { Zinc } \\
\text { recovered }\end{array}$ \\
\hline & & & & & & & Years & Mtpa & $\%$ & Mt (life) \\
\hline $\begin{array}{l}\text { Board } \\
\text { approved } \\
\text { original } \\
\text { development } \\
\text { plan }\end{array}$ & $\begin{array}{c}\text { Dec } \\
2012\end{array}$ & \multirow{2}{*}{$\begin{array}{c}\text { SLOS (N\&S) } \\
(25 \times 25)+D R \\
\text { process }\end{array}$} & 4.3 & 12.1 & 5.2 & 2.1 & 21 & 2.1 & 87 & 4.53 \\
\hline $\begin{array}{l}\text { Continue as } \\
\text { per original } \\
\text { development } \\
\text { plan (MMR) }\end{array}$ & $\begin{array}{l}\text { Aug } \\
2013\end{array}$ & & 33.7 & 11.3 & 3.8 & $\begin{array}{c}10 \text { years } 2.0 \\
7 \text { years } 1.5\end{array}$ & 20 & 2.0 & 87 & 3.3 \\
\hline $\begin{array}{l}\text { Revised } \\
\text { Development } \\
\text { plan (MMR) }\end{array}$ & $\begin{array}{l}\text { Aug } \\
2013\end{array}$ & $\begin{array}{c}\text { SLOS (N\&S) } \\
(25 \times 15)+\text { DR } \\
\text { process }\end{array}$ & 32.6 & 12.1 & 3.9 & 1.55 & 23 & 2.0 & 87 & 3.4 \\
\hline $\begin{array}{l}\text { Revised } \\
\text { development } \\
\text { plan (PFS draft) }\end{array}$ & $\begin{array}{c}\text { Feb } \\
2015\end{array}$ & $\begin{array}{c}25 \mathrm{~m} \text { benching } \\
\mathrm{N}+\mathrm{SLOS} \\
(25 \times 13 \text { to } 30) \mathrm{S}\end{array}$ & 38.2 & 12.2 & 4.6 & 1.5 & 30 & 1.7 & 87.2 & 4.05 \\
\hline
\end{tabular}

\subsection{Value engineering of processing options}

A 2 Mtpa process plant was previously designed for the Dugald River project, and major items of equipment were purchased. Based on the updated mine plan, the process plant design was revised for a nominal throughput of $1.5 \mathrm{Mtpa}$ and a maximum throughput of $1.75 \mathrm{Mtpa}$.

As far as possible, key design aspects have been retained from the $2 \mathrm{Mtpa}$ design and as much pre-purchased equipment as possible has been retained in the design. In essence, the approach has been to take the $2 \mathrm{Mtpa}$ design and to re-scale it for a smaller facility. As is prudent, a number of value improvement opportunities have also been identified and included in the revised design of the process plant and other surface infrastructure.

\subsection{Ongoing project risk}

Mitigation of the technical risk, which was a weakness in the 2009 feasibility study, has occurred through the various detailed studies that have followed. However, project risk still does and will always remain. The risk characterisation of the project is summarised in the following points:

- The orebody is a single lode with complex geology and low tonnes per vertical metre.

- Variable orebody grades, geotechnical structures and a weak hanging wall threaten to reduce plant feed grades further if poor mining practice is applied.

- The project is also challenged by a significant proportion of the orebody being at operational depths greater than $600 \mathrm{~m}$. At depths below $400 \mathrm{~m}$, geotechnical conditions and mining-induced stress impacts on mine development rates and ground support requirements, resulting in higher mining costs.

- The operational depth also means that it is hard to gain high levels of resource confidence, as declines have to be continuously developed well in advance to create diamond drilling platforms.

- The low vertical tonnes per metre mean that high annual development rates have to be maintained to ensure production. 
- These risks are not unusual for narrower single-lode orebodies in Australia. Many gold mines and nickel mines in Western Australia have similar risk profiles and have been operated successfully for many years. Such mines rarely have more than five years of the mineralised inventory classified to reserve status. In some cases, such mines have no more than two years of reserves estimated (despite having a large resource base). Many mines in Africa and Canada also have similar risk profiles and characteristics. Experience has also shown that these types of mines can be successful by ensuring that high levels of operational and geological control, decline and drilling platform development rates are maintained; that geological definition and resource conversion drilling is carried out annually; and that the ore resources/reserve is extracted according to the design sequence.

- The key differences that increase the financial risk profile for Dugald River compared to other similar mines are:

- The uniform nature of the grade, meaning that high production rates are required to pay back infrastructure capital and initial investment.

- That mine infrastructure has to be established quicker because of the low tonnes per vertical metre, resulting in an increase of upfront capital costs.

\section{Conclusion}

Converting a mineral deposit into a mining operation is an extremely complex process, and it is not unusual for development activity to identify conditions more challenging than prior assumptions.

In the case of Dugald River, the decision to undertake comprehensive mine method and business option reviews upon identification of geotechnical and ground conditions more challenging than prior assumptions while difficult, represents a prudent response in the long-term interests of a project.

This, coupled with the subsequent decision to undertake a trial stoping program to gain practical mining experience and determine revised operating parameters enabled MMG to further mitigate identified risk and develop an updated project plan that maximises long-term project value.

\section{Acknowledgement}

The author thanks MMG Limited for permission to publish the paper.

\section{References}

AMC Consultants 2008, Dugald River feasibility study geotechnical, external consultant report for MMG Limited.

AMC Consultants 2013, Dugald River mining methods review, external consultant report for MMG Limited.

Capes, G 2009, 'Open stope hangingwall design based on general and detailed data collection in rock masses with unfavourable hangingwall conditions', PhD thesis, University of Saskatchewan.

Carswell, J, Player, J, de Vries, R \& Hassell, R 2015, Sublevel open stoping hanging wall Instrumentation Program at the Dugald River underground mine, in PM Dight (ed.), Proceedings of the Ninth International Symposium on Field Measurements in Geomechanics, Australian Centre for Geomechanics, Perth, pp. 551-564.

de Vries, R, Hassell, R \& Player, J 2015, Geotechnical design considerations for Dugald River - from slot to sequence, in Y Potvin (ed.) Proceedings of the International Seminar on Design Methods in Underground Mining, Australian Centre for Geomechanics, Perth.

Hassell, R, de Vries, R, Player, J \& Rajapakse, A 2015a, 'Dugald river trial stoping, overall hangingwall behaviour', in Y Potvin (ed.) Proceedings of the International Seminar on Design Methods in Underground Mining, Australian Centre for Geomechanics, Perth.

Hassell, R, Villaescusa, E, de Vries, R \& Player, J 2015b, 'Stope blast vibration analysis at the Dugald River underground mine', Proceedings of the 11th International Symposium on Rock Fragmentation by Blasting (Fragblast 11), The Australasian Institute of Mining and Metallurgy, Melbourne.

MMG Limited 2009, Dugald River project feasibility study, internal report, MMG Limited, Melbourne.

MMG Limited 2013, Dugald River business options review report, internal report, MMG Limited, Melbourne.

MMG Limited 2015, Dugald River updated development plan report, internal report, MMG Limited, Melbourne. 